\title{
DETERMINANTS OF RETURN INTENTION OF VISITORS: AN INVESTIGATIVE STUDY IN PHU QUOC ISLANDS, VIETNAM
}

\section{Le Thanh Tung - Tran Quoc An - Nguyen Hong Thai}

\begin{abstract}
The Vietnamese tourism sector was fastly growing in several years, this sector also has played an important role in support the social development in Vietnam. Our paper tries to analysis the factors affect return intention of visitors with the data sample are collected from a survey including 230 visitors in Phu Quoc islands, which is the most well known and beautiful one in Vietnam. The research model has one dependent variable which is Return intention and eight independence variables including Destination Image, Natural and Cultural Environment, Perceived Price, Infrastructure, Accessibility, Local Cuisine, Leisure and Entertainment, and Attitude of the local people. The results show that all independent variables also have the positive effects on the Return intention of visitors at the statistical significance at $5 \%$ level. Finally, our paper provides some suggestions which are useful for managers in the tourist service sector and academics in the service economics field.
\end{abstract}

Key words: return intention, visitors, tourism, Phu Quoc island, Vietnam.

JEL Code: M21, M31, M38

\section{Introduction}

In the Vietnamese map, Phu Quoc island is located in the Gulf of Thailand and is the largest island in Vietnam. The island has a total area of 574 square kilometers and the population is approximate 103,000 people. For several years, Phu Quoc island has been ranked by some well-known papers as one of the most beautiful islands in the world, such as Rough Guides, CnTraveler, Huffington Post. For several years, Phu Quoc island has been ranked by some well-known papers as one of the most beautiful islands in the world, such as Rough Guides, CnTraveler, Huffington Post. The tourism sector in Phu Quoc has flourished and significantly contributed to promoting the socio-economic development of Vietnam. The number of tourist arrivals and tourism revenue is increasing, tourist products are more diversified and diversified, contributing significantly to increasing state budget revenues, job creation and improving living standards of local people. According to the statistics of Kien Giang Statistics 
Department, the number of tourists to Phu Quoc increased sharply with the high average growth rate in several years. If there were only about 1 million visitors in 2007, however, there were nearly 3 million tourists come to Phu Quoc in 2016. In the period 2009-2016, the growth in the number of visitors to Phu Quoc increased by an average of $40 \%$ and the number of tourists in recent years has increased more and more rapidly. This is a good sign, but the low spending, the short stay time, the focus at the holidays and the weekend should also be a challenge for the tourism industry in Phu Quoc island.

For several years, the most important target of the tourism sector in Vietnam in general, as well as the tourism in Phu Quoc island in particular, was only to increase the number of tourists and completely abandon the solutions in order to convince the tourists to return in the future. Actually, the cost of convincing a customer to return is much lower as well as greater efficiency than attracting a new one. The returning customers not only increase revenue but also a very effective social media channel for the destinations. The good experiences and sharing from visitors will become a very reliable reference source that many new visitors will refer to when they try to find a good destination (Shoemaker and Lewis, 1999). However, according to the survey conducted by the Vietnam National Administration of Tourism in 2014, most of the visitors to Vietnam (including Phu Quoc island) were their first time, which was calculated about $90 \%$ of total arrivals coming in the country. At the returning information of visitors, the statistics also showed that the rate of the visitors came back in as the second times was only $6 \%$. So we can see that the rate of the number of the tourists who returned to a Vietnamese destination (including Phu Quoc island) was only about $10 \%$ compared the total quantity. By the way, we can see that the study has stopped at the statistical description of the survey, It had not got any analysed research to answer the questions of this evidence, example as " Why has very small of the rate of returning visitors?" or "What are the factors impact on the returning decision of visitors?" or "How government officers and businesses need to do if they want to have more returning visitors?"

Because of the miss in the information in this situation, so many businesses, as well as local agencies, are faced with many difficult points and still struggling in the ways to have the efficient solutions to increase the rate of the returning visitors. Therefore, our study will provide the investigated evidence to suggest many administrative implications for tourism enterprises as well as government officers in Phu Quoc island in particular and Vietnam in order to attract more returning tourists in next time.

\section{Literature review}


There are a number of theories that explore the behavior of consumer such as Theory of Reasoned Action (TRA) developed by Ajizen and Fishbein (1975) to study consumer behavior. In fact, the TRA is considered one of the pioneering theories in the research field of consumer behavior when choosing a particular type of goods or services. The TRA theory shows that consumer behavior is determined by the intention to do that behavior (Ajzen, 1988). The Theory of Planned Behavior (TPB) was developed by Ajzen (1991) from the improvement of the Theory of Reasoned Action. According to the TPB, motivation or intention is a fundamental motivator of human consumption behavior. The motives or intentions driven by the three basic prefixes are attitudes, subjective norms, and cognitive behavioral control. The more resources and opportunities they have, the fewer obstacles they will have and the greater the cognitive control of behavior. In addition, Holbrooke and Batra (1987) have developed a Cognition- Affect- Behavioral Paradigm model (C-A-B) to explain how the cognitive buyers behave. This model can explain the cause-and-effect relationship of customer behavior. Based on this theory, we can assume what the visitors think and trust about the destination information will affect how they feel and can control their intentions of returning to the destination.

Jones and Sasser (1995) suggested that there would be acquisition behavior if consumers were satisfied after purchase process. According to Weber's (1996) approach, the customer satisfaction is one of the most important factors of the marketing theory and has an important influence on customers purchase intentions in future, through the Word of mouth (WOM) channel. Oliver (1997) showed that the loyalty was a behavioral commitment toward buying products or using services in the future. Kotler and Armstrong (1999) also point out that if consumers are satisfied with the quality of service provided by the company (or even higher than expected consumers expect), the consumers will repurchase or introduce others.

According to the studies done by Chen and Tsai (2007), Oppermann (2000), the level of loyalty to a destination is reflected in its willingness to return and willingness to introduce it to others. Homburg and Giering (2001) measured "intentional behavior in the future" by two indicators: intentions of repurchase and intention to refer to others. In the field of the tourism sector, the same approach is expressed by the intention to return and be openly introduced to others (Oppermann, 2000; Chen and Gusoy, 2001). Based on the study result of Yan et al. (2007), the cost of acquiring a new customer is five times larger than keeping an old customer. Consequently, companies want to keep the relationships with their old customers and hopefully increase their repurchase intentions. 
These are some empirical studies in the tourist in the Asian region. Thiumsak and Ruangkanjanases (2016) studied the factors affecting international travelers returning to Bangkok, Thailand. The research result showed these had got five independent variables influencing the revisiting intention of international tourists to Bangkok, Thailand. They are the Perceived satisfaction on destination attributes, Overall satisfaction, Perceived attractiveness on destination attributes, Overall destination image, and Tourist's motives. The study was done by Khuong and Trinh (2015) which focused on the factors affecting the return intention of visitors to Vung Tau City, Vietnam. The relationship between the variables including the Novelty seeking, Natural and cultural environment, Safety and security, Leisure and entertainment, Local cuisine, Infrastructure, Accessibility, Price, Negative attributes, and Destination image might lead to the intention of the return of visitors.

\section{Research model and Data}

Based on the reference from the previous studies (Khuong and Trinh, 2015; Thiumsak and Ruangkanjanases, 2016), our research model has one dependence variable (Return intention) and 8 independence variables including the Destination Image, Natural and Cultural Environment, Perceived Price, Infrastructure, Accessibility, Local Cuisine, Leisure and Entertainment, and Attitude of the local people. Our study model is represented in the following form:

\section{Fig. 1: Research model.}




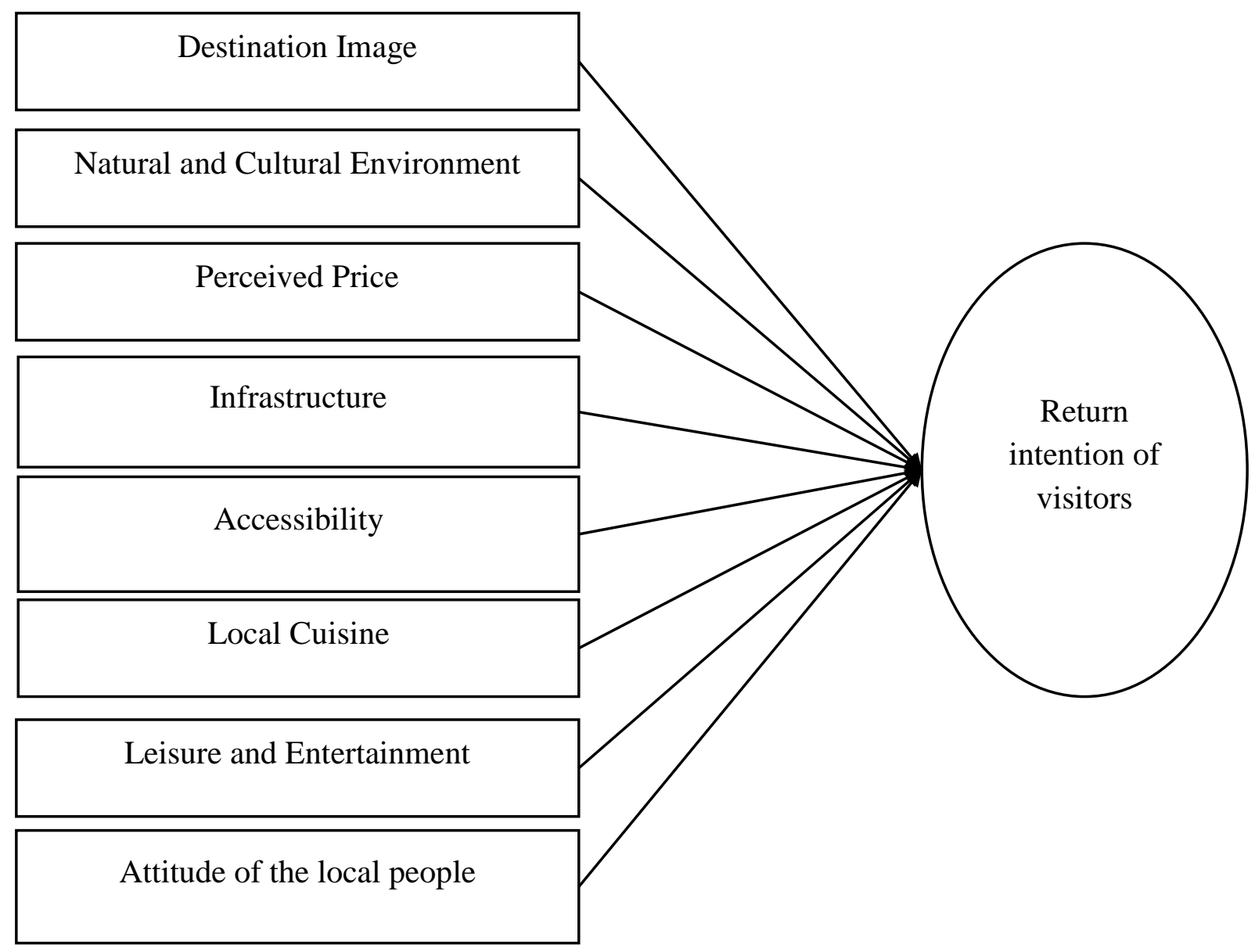

Source: Research results by authors

The hypothesis $\mathrm{H} 1$ to $\mathrm{H} 8$ are the independent variables impacts to the dependent variable the return intention of visitors. The hypothesises of our model are presented as follows:

Hypothesis H1: The return intention of visitors is positively affected by the Destination Image.

Hypothesis H2: The return intention of visitors is positively affected by the Natural and Cultural Environments.

Hypothesis H3: The return intention of visitors is positively affected by the Perceived Price.

Hypothesis H4: The return intention of visitors is positively affected by the Infrastructure.

Hypothesis H5: The return intention of visitors is positively affected by the Accessibility.

Hypothesis H6: The return intention of visitors is positively affected by the Local Cuisine. 
Hypothesis H7: The return intention of visitors is positively affected by the Leisure and Entertainment.

Hypothesis H8: The return intention of visitors is positively affected by the Attitude of the local people.

we do a survey in order to analyse the determinants of return intention of visitors in Phu Quoc islands. The research data is collected by a questionnaire survey with a sample size of 300 visitors through both hard-copy paper and email on the internet. Finally, there are 233 valid votes (as 77.67\%) which are passed over the screening step to conduct quantitative analysis in the next section. Results of the descriptive statistics are presented below.

Tab. 1: Description statistic of the research sample.

\begin{tabular}{|c|c|c|c|}
\hline & Characteristic & $\begin{array}{c}\text { Frequency } \\
(n=233)\end{array}$ & $\begin{array}{c}\text { Percentage } \\
(\%)\end{array}$ \\
\hline \multirow{2}{*}{ Gender } & Female & 133 & 57.8 \\
\hline & Male & 97 & 42.2 \\
\hline \multirow{4}{*}{ Age } & $\leq 18$ to 30 & 90 & 39.1 \\
\hline & $\leq 31$ to 40 & 64 & 27.8 \\
\hline & $\leq 41$ to 50 & 47 & 20.4 \\
\hline & $>50$ & 29 & 12.6 \\
\hline \multirow{4}{*}{ Education } & Vocational school & 46 & 20.0 \\
\hline & Under graduate & 56 & 24.3 \\
\hline & Graduate & 106 & 46.1 \\
\hline & Post graduate & 22 & 9.6 \\
\hline \multirow{4}{*}{ Income } & $<10$ million VND & 83 & 36.1 \\
\hline & $\leq 10$ to 20 million $\mathrm{VND}$ & 107 & 46.5 \\
\hline & $\leq 21$ to 30 million $\mathrm{VND}$ & 35 & 15.2 \\
\hline & $>30$ million VND & 5 & 2.2 \\
\hline
\end{tabular}

Source: Calculated from the research data

Quantitative research methods are used in this study. Theoretical models have five independent concepts measured by 32 observed concepts and one dependent concept measured by 4 observed concepts. Scale concepts studied in theoretical models are multivariate scale. The observed concepts are measured on a 5-points Likert scale (1: strongly 
disagree to 5: strongly agree). It is divided into 2 parts. Part 1 includes the question about personal information such as gender, age, education level and income. Part 2 is the question which measures the determinants of return intentions of visitors. The questions to measure the return intention of visitor are sourced from Thiumsak and Ruangkanjanases (2016) and the items which are described as the determinants of the return intention are sourced from Khuong and Trinh (2015) and Thiumsak and Ruangkanjanases (2016).

\section{Empirical results}

The scales of factors affecting the return intention of visitors to Phu Quoc island are measured by Cronbach's Alpha test and Exploratory Factor Analysis. The results of the testing (Table 2) showed that the reliability was high (Cronbach's Alpha> 0.7), the correlation coefficients of the scales were higher than 0.3 , so we can conclude that all the scales are reliability (Nunnally and Burnstein, 1994) and also are used to analyse in the next step.

Tab. 2: Results of testing the scales.

\begin{tabular}{|l|c|r|r|r|}
\hline \multicolumn{1}{|c|}{ Variable } & Symbol & Item & $\begin{array}{r}\text { Cronbach } \\
\text { 's Alpha }\end{array}$ & $\begin{array}{r}\text { Minimum value of } \\
\text { Corrected Item- } \\
\text { Total Correlations }\end{array}$ \\
\hline Destination Image & DE & 4 & 0.937 & 0.811 \\
\hline Natural and Cultural Environment & NA & 4 & 0.933 & 0.791 \\
\hline Perceived Price & PE & 4 & 0.913 & 0.761 \\
\hline Infrastructure & IN & 4 & 0.978 & 0.693 \\
\hline Accessibility & AC & 4 & 0.883 & 0.704 \\
\hline Local Cuisine & LO & 4 & 0.885 & 0.730 \\
\hline Leisure and Entertainment & LE & 4 & 0.907 & 0.719 \\
\hline Attitude of the local people & AT & 4 & 0.946 & 0.638 \\
\hline Return intention & RE & 4 & 0.863 & \\
\hline
\end{tabular}

Source: Calculated from the research data.

In this step, we use the Explore Factor Analysis technique with Extraction method (Principal Component Analysis) and Rotation method (Varimax with Kaiser Normalization) to analysis our survey data. The Factor analysis result for the independent variables is reported in Table 3. The result shows that the load factor of 32 variables is greater than 0.5 
(Hair et al., 1998), the Eigenvalue values are greater than 1 as well as the Rotation Sums of Squared Loadings is $84.24 \%$. Thus, the observed concepts are correlated with each other considering the overall scope. The variables are used to analyse the model using multiple linear regression.

Tab. 3: Analysis of factors for the independent variables.

\begin{tabular}{|c|c|c|c|c|c|c|c|c|}
\hline \multirow{2}{*}{ Variable } & \multicolumn{8}{|c|}{ Item } \\
\hline & 1 & 2 & 3 & 4 & 5 & 6 & 7 & 8 \\
\hline AT2 & 0.940 & & & & & & & \\
\hline AT3 & 0.901 & & & & & & & \\
\hline AT4 & 0.886 & & & & & & & \\
\hline AT1 & 0.882 & & & & & & & \\
\hline DE3 & & 0.886 & & & & & & \\
\hline DE1 & & 0.873 & & & & & & \\
\hline DE4 & & 0.839 & & & & & & \\
\hline DE2 & & 0.823 & & & & & & \\
\hline NA4 & & & 0.842 & & & & & \\
\hline NA2 & & & 0.835 & & & & & \\
\hline NA3 & & & 0.833 & & & & & \\
\hline NA1 & & & 0.813 & & & & & \\
\hline PE3 & & & & 0.889 & & & & \\
\hline PE1 & & & & 0.859 & & & & \\
\hline PE2 & & & & 0.851 & & & & \\
\hline PE4 & & & & 0.827 & & & & \\
\hline LE4 & & & & & 0.862 & & & \\
\hline LE1 & & & & & 0.835 & & & \\
\hline LE3 & & & & & 0.835 & & & \\
\hline LE2 & & & & & 0.778 & & & \\
\hline $\mathrm{AC} 4$ & & & & & & 0.871 & & \\
\hline AC3 & & & & & & 0.840 & & \\
\hline $\mathrm{AC} 1$ & & & & & & 0.815 & & \\
\hline $\mathrm{AC2}$ & & & & & & 0.802 & & \\
\hline LO1 & & & & & & & 0.834 & \\
\hline LO4 & & & & & & & 0.828 & \\
\hline $\mathrm{LO} 2$ & & & & & & & 0.823 & \\
\hline LO3 & & & & & & & 0.802 & \\
\hline IN1 & & & & & & & & 0.854 \\
\hline IN3 & & & & & & & & 0.821 \\
\hline IN4 & & & & & & & & 0.821 \\
\hline IN2 & & & & & & & & 0.755 \\
\hline$\%$ of Variance & 11.151 & 11.006 & 10.457 & 10.200 & 9.902 & 9.633 & 9.551 & 9.340 \\
\hline Eigenvalues & 9.570 & 3.401 & 2.767 & 2.590 & 2.347 & 2.139 & 1.692 & 1.491 \\
\hline KMO $=\mathbf{0 . 7 3 8}$ & & & & Sig. $=0$ & 0000 & & & \\
\hline
\end{tabular}

Source: Calculated from the research data. 
As the information in Table 4, the result of Explore Factor Analysis of the dependent variable factor has $\mathrm{KMO}$ coefficient $=0.816$ and test Barlett has Sig $=0.000$. Load factor coefficient is greater than 0.5 and \% of Variance of Initial Eigenvalues reached $71.04 \%$, hence there are no variables were excluded.

Tab. 4: Analysis of factors for the dependent variables.

\begin{tabular}{|c|c|}
\hline Variable & Component \\
\hline RE2 & 0.884 \\
\hline RE3 & 0.851 \\
\hline RE1 & 0.846 \\
\hline RE4 & 0.787 \\
\hline \% of Variance & 71.048 \\
\hline Eigenvalues & 2.842 \\
\hline KMO $=\mathbf{0 . 8 1 6}$ & Sig. $=0.0000$ \\
\hline
\end{tabular}

Source: Calculated from the research data.

The first step of conducting linear regression analysis is to consider the linear correlation between all the variables in the research model. We use the Pearson correlation matrix to consider the overall relationship between each independent variable with the dependent variable, and between the independent concepts in the function.

Tab. 5: Pearson correlation matrix results.

\begin{tabular}{|c|c|c|c|c|c|c|c|c|c|c|}
\hline \multicolumn{2}{|c|}{ Variable } & $\mathrm{RE}$ & $\mathrm{DE}$ & NA & $\mathrm{PE}$ & IN & $\mathrm{AC}$ & $\mathrm{LO}$ & LE & AT \\
\hline $\mathrm{RE}$ & $\begin{array}{c}\text { Pearson } \\
\text { Correlation }\end{array}$ & 1 & & & & & & & & \\
\hline $\mathrm{DE}$ & $\begin{array}{c}\text { Pearson } \\
\text { Correlation }\end{array}$ & $.659 * *$ & 1 & & & & & & & \\
\hline $\mathrm{NA}$ & $\begin{array}{c}\text { Pearson } \\
\text { Correlation }\end{array}$ & $.669 * *$ & $.485^{* *}$ & 1 & & & & & & \\
\hline $\mathrm{PE}$ & $\begin{array}{c}\text { Pearson } \\
\text { Correlation }\end{array}$ & $.426 * *$ & $.231 * *$ & $.277 * *$ & 1 & & & & & \\
\hline IN & $\begin{array}{c}\text { Pearson } \\
\text { Correlation }\end{array}$ & $.474 * *$ & $.315^{* *}$ & $.344 * *$ & $.178 * *$ & 1 & & & & \\
\hline $\mathrm{AC}$ & $\begin{array}{c}\text { Pearson } \\
\text { Correlation }\end{array}$ & $.366^{* *}$ & $.255^{* *}$ & $.203 * *$ & $.245^{* *}$ & $.278 * *$ & 1 & & & \\
\hline $\mathrm{LO}$ & $\begin{array}{c}\text { Pearson } \\
\text { Correlation }\end{array}$ & $.462 * *$ & $.365^{* *}$ & $.362 * *$ & $.310 * *$ & $.303 * *$ & $.214 * *$ & 1 & & \\
\hline $\mathrm{LE}$ & $\begin{array}{c}\text { Pearson } \\
\text { Correlation }\end{array}$ & $.496 * *$ & $.393 * *$ & $.473 * *$ & $.356^{* *}$ & $.266 * *$ & $.161 * *$ & $.187 * *$ & 1 & \\
\hline
\end{tabular}


The $12^{\text {th }}$ International Days of Statistics and Economics, Prague, September 6-8, 2018

\begin{tabular}{|c|c|c|c|c|c|c|c|c|c|c|}
\hline AT & $\begin{array}{c}\text { Pearson } \\
\text { Correlation }\end{array}$ & $.381 * *$ & $.159 * *$ & $.285 * *$ & $.218 * *$ & $.257 * *$ & $.289 * *$ & $.203 * *$ & $.179 * *$ & 1 \\
\hline
\end{tabular}

Notes: **, Pearson correlation at the significance of $5 \%$ level

Source: Calculated from the research data.

Results of the correlation matrix (Table 5) shows the dependent variable correlates quite closely linear between 8 independent variables. The correlation coefficient between these variables ranged from 0.159 to 0.669 with the statistical significance level is $5 \%$.

Tab. 6: Model Summary.

\begin{tabular}{|c|c|c|c|c|c|}
\hline Model & $\mathbf{R}$ & $\mathbf{R}^{\mathbf{2}}$ & Adjusted R Square & Std. Error of the Estimate & Durbin-Watson \\
\hline 1 & 0.838 & 0.702 & 0.692 & 0.39188 & 2.091 \\
\hline
\end{tabular}

Source: Calculated from the research data.

Tab. 7: Estimated Coeficients.

\begin{tabular}{|c|r|r|r|r|r|}
\hline \multirow{2}{*}{ Variable } & $\begin{array}{c}\text { Standardized } \\
\text { Coefficients } \\
\text { (Beta) }\end{array}$ & \multirow{2}{*}{$\mathbf{t}$} & \multicolumn{1}{|}{ Sig. } & \multicolumn{2}{|c|}{ Collinearity Statistics } \\
\cline { 6 - 7 } & 0.332 & 7.388 & 0.000 & 0.668 & 1.496 \\
\hline DE & 0.298 & 6.323 & 0.000 & 0.606 & 1.650 \\
\hline NA & 0.136 & 3.285 & 0.001 & 0.783 & 1.277 \\
\hline PE & 0.138 & 3.334 & 0.001 & 0.782 & 1.278 \\
\hline IN & 0.081 & 2.010 & 0.046 & 0.827 & 1.210 \\
\hline AC & 0.090 & 2.138 & 0.034 & 0.753 & 1.328 \\
\hline LC & 0.088 & 1.977 & 0.049 & 0.684 & 1.462 \\
\hline LE & 0.120 & 2.996 & 0.003 & 0.836 & 1.196 \\
\hline AT & & & & & \\
\hline
\end{tabular}

Source: Calculated from the research data.

The estimated results of the multiple regression model indicate a good fitness with the data $(\mathrm{F}=65,187, \mathrm{p}<0.001 ; \mathrm{R} 2=70.2 \%$; all VIFs $<2.0)$. The result of the factors which determinate the return intention of visitors is shown in Table 7. We can see that all of the independent variables have the positive impact on the return intention of visitors in Phu Quoc island. Based on the estimated results, we can conclude that the Destination Image (DE) is the highest positive effect on the return intention of visitors. By the ways, we can rank from the highest to the lowest including the Natural and Cultural Environment (NA), Perceived Price (PE), Infrastructure (IN), Attitude of the local people (AT), Local Cuisine (LC), Leisure and 
Entertainment (LE), and Accessibility (AC). Furthermore, the estimated result is confirmed all of our study hypothesis from $\mathrm{H} 1$ to $\mathrm{H} 8$.

\section{Conclusion}

The article aims to study the factors that affect the return intention of visitors by the sample of 233 customers to Phu Quoc island, Vietnam. The research model consists of eight independent variables (which may have the effect on the return intention) and one dependent variable (the return intention of visitors). The study result showed that all independent variables have positive effects on the return intention to the destination of visitors. This finding is valuable to both the government officers and the tourist businesses. Based on the results of the study, we have some the suggestions as the following:

The first: The Destination Image (DE) variable (with the beta is 0.332) has the strongest impact on the intent to return to the destination of visitors compared the others. Therefore, to convince tourists to return to Phu Quoc island more and more, both the government officers and the tourist businesses need have solutions to impress tourists by the creating a nicer picture of the cities in the Phu Quoc island. Local governments also may think of re-arranging of all local restaurants, hotels, resorts, shopping outlets or entertainment venues. From there, the image of the cities becomes more professional, and the order also creates conditions for visitors to enjoy the beautiful beaches, using all the tourist products and services of the island.

The second: The Natural and Cultural Environment (NA) variable has a beta value is 0.298, suggesting that this factor has a positive effect on the return intention of visitors to the tourist destination. So the businesses need to keep and restore the old and traditional places, the icons of the past heroic revolution in the island as well as try to collect the stories about the local revolutionary tradition. Phu Quoc island is a place of diverse cultures with longstanding indigenous people in Vietnam, so it is important to show these cultural characteristics to tourists quickly and widely in the future.

The third: Perceived Price (PE) variable (with the beta value is 0.133 ) also has a positive effect on the return intention of visitors. Both the government officers and the businesses need to keep a stable common price for goods and services. Local authorities should strictly control the prices of all stores from the restaurants, hotels, motels, shopping centers or entertainment venues. The local governments need some strategies to prevent price escalation during special holidays or long vacations on the island. In addition, the price policy should be introduced to tourists and local people to protect all travelers from price 
discriminatory treatment. Specifically, the prices must be clearly written on the menus and noted when there are any changes or price increases during the holiday, the menus must mention all the information for visitors.

The fourth: The Infrastructure (IN) variable has the beta is 0.138 implies that this factor has a positive impact on the return intention visitors to the tourist destinations. Thus, the good infrastructure will help visitors have more favorable when they visit the scenic spots. To enhance the accessibility of visitors to Phu Quoc island, local authorities need to upgrade the infrastructure facilities in order to faster link to local hotels, restaurants, resorts and the recreational facilities. They will become high-quality relaxation places with international standards. In addition, the government should expand and renew the Phu Quoc international airport and build new roads connecting the airport to the cities in this island.

The fifth: The Attitude of the local people (AT) variable (beta $=0.120)$ had a positive effect on the return intention of visitors. The marketers in the tourism industry in the island should propagate, promote a positive image of the friendly and hospitable people in the local cities in Phu Quoc island. At the same time, the government should also create a public education campaign about the importance of tourism and encourage the local people to more friendly and hospitable with tourists. Promote community-based activities to create a stable life and maintain cultural values of friendly people in Asia.

The sixth: The Local Cuisine factor (with the beta value is 0.081 ) had a positive impact on the return intention to tourist destinations. The government should encourage the businesses to invest in many types of restaurants and hotels catering to visitors to choose a variety of cuisine appropriate to introduce the Phu Quoc 's cuisine. To enhance competitiveness in this area, local authorities should monitor the quality and hygiene of food provided by suppliers and restaurants to maintain high-quality perceptions from tourists. The local restaurants, hotels or tourist sites must strictly comply with the regulations on food hygiene and safety.

The seventh: The Leisure and Entertainment (LE) factor (with a beta factor of 0.088) has a positive influence on the return intention to a tourist's destination. Therefore, the tourist companies should invest more resources to build some unique amusement parks or entertainment places with a variety of games ranging from thrilling, adventurous to gently styled, able to meet the diverse needs of guests. In addition, local tourism companies need to cooperate well with other tourism managers in other provinces as well as other countries near Vietnam, helping travelers to travel to different provinces or link Phu Quoc island (Vietnam) and other countries match on a trip. 
The eighth: The Accessibility variable $(\mathrm{AC})($ with beta $=0.081$ ) has the lowest effect on the return intention of visitors compared others. Local authorities should provide visitors with quick and accurate information by providing tourist information, shopping, dining, travel services and accommodation free of charge at all times. They need to build some fast and beautiful websites to introduce the Phu Quoc island. Big traffic system in Phu Quoc, such as bus stop, large junction, airport, etc. In addition, businesses in the service industry should encourage online shopping with free delivery service to Facilitate tourists to save time shopping (especially to the visitors with little time) in Phu Quoc. Local governments should control, monitor and apply security policies to avoid the unsafe for visitors, and set up a free hotline to assist visitors when they need contact with the local government.

\section{References}

Ajzen, I., \& Fishbein, M. (1975). “Theory of reasoned actions as applied to moral behavior: A confirmatory analysis." Journal of Personality and Social Psychology, 62, 98 - 109.

Ajzen, I. (1991). "The theory of planned behavior." Organizational Behavior and Human Decision Processes, 50 (2), 179-211.

Chen, C. F., \& Tsai, D. (2007). "How destination image and evaluative factors affect behavioural intentions?", Tourism Management, 28, 1115-1122.

Chen, J, \& Gursoy, D. (2001). "An investigation of tourists' destination loyalty and preferences.", International Journal of Contemporary Hospitality Management, 13 (2), 79-85.

Jones, T., \& Sasser, W. (1995). "Why Satisfied Customers Defect." Harvard Business Review, 73 (6) (November-December 1995).

Khuong, M., \& Trinh, N. (2015). “Factors affecting tourists's return intention towards Vung Tau city, Vietnam - A mediation analysis of Destination satisfaction", Journal of Advanced Management Science, 3 (4), 292-298.

Oliver, L. (1997). Satisfaction: A behavioral perspective on the consumer. New York: Irwin/McGraw-Hill.

Oppermann, M. (2000). "Triangulation — a methodological discussion.", International journal of Tourist research, 2 (2), 141-145. 
Hair, J., Anderson, E., Tatham, R., \& Black, W.C., (1998). Multivariate Data Analysis (5th ed.), Prentice Hall, Upper Saddle River, New Jersey.

Holbrook, M. B., \& Batra, R. (1987). "Assessing the role of emotions as mediators of consumer responses to advertising." Journal of Consumer Research, 14 (3), 404-420.

Homburg, C., \& Giering, A. (2001) "Personal Characteristics as Moderators of the Relationship Between Customer Satisfaction and Loyalty - An Empirical Analysis." Psychology and Marketing, 18 (1), 43-66.

Nunnally, J. C., \& Bernstein, I. H. (1994). Psychometric theory (3rd ed.). New York, NY: McGraw-Hill, Inc.

Philip Kotler, P. \& Armstrong, G. (1999). Principles of Marketing, New Jersey: Prentice Hall.

Shoemaker, S. \& Lewis, R. C. (1999) "Customer loyalty: The future of hospitality marketing”, Hospitality Management, 18, 345-370.

Tun Thiumsak, T., \& Ruangkanjanases, A. (2016). "Factors Influencing International Visitors to Revisit Bangkok, Thailand." Journal of Economics, Business and Management, 4 (3), 220-230.

Yan, W., Chen, C.-H., \& Khoo, L. P. (2007). ’Identification of Different Demographical Customer Preferences for Product Conceptualization", Journal of Engineering Design, 18(1), 39-54. 


\section{Contact}

Le Thanh Tung

Faculty of Economics and Public Management, Ho Chi Minh City Open University 97 Vo Van Tan street, Ward 6, District 3, Ho Chi Minh City, Vietnam

Email: tung.lt@ou.edu.vn

Tran Quoc An

The Management Board of Phu Quoc Economic Zone

17 Nguyen Chi Thanh, Phu Quoc, Kien Giang, Vietnam

Email: andautu@gmail.com

Nguyen Hong Thai

Faculty of Transport Economics, University of Transport and Communications

03 Cau Giay street, Lang Thuong Ward, District Dong Da, Ha Noi, Vietnam.

Email: thaidhgt@yahoo.com 